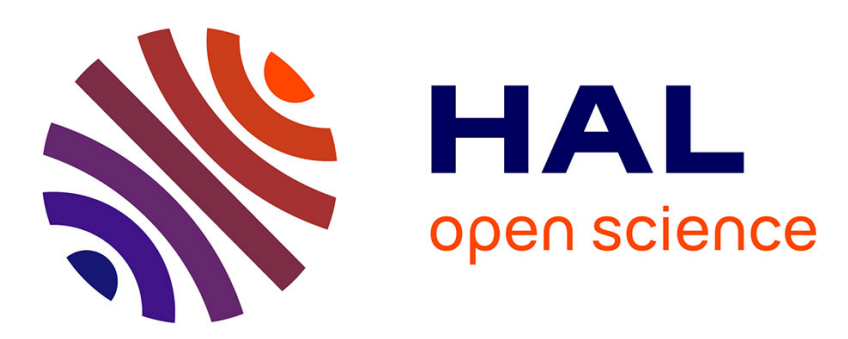

\title{
ANRT Lille: the French national centre for the reproduction of $\mathrm{PhD}$ theses
}

\author{
Joachim Schöpfel
}

\section{To cite this version:}

Joachim Schöpfel. ANRT Lille: the French national centre for the reproduction of $\mathrm{PhD}$ theses. Interlending and Document Supply, 2013, 41 (1), pp.3 - 6. 10.1108/02641611311313016 . sic_01079513

\section{HAL Id: sic_01079513 \\ https://archivesic.ccsd.cnrs.fr/sic_01079513}

Submitted on 2 Nov 2014

HAL is a multi-disciplinary open access archive for the deposit and dissemination of scientific research documents, whether they are published or not. The documents may come from teaching and research institutions in France or abroad, or from public or private research centers.
L'archive ouverte pluridisciplinaire HAL, est destinée au dépôt et à la diffusion de documents scientifiques de niveau recherche, publiés ou non, émanant des établissements d'enseignement et de recherche français ou étrangers, des laboratoires publics ou privés. 


\title{
ANRT Lille: The French National Centre for the Reproduction of PhD Theses \\ Joachim Schöpfel \\ University of Lille
}

\begin{abstract}
Purpose - The article describes the ANRT, its purpose and activity in the French national network for the dissemination and preservation of $\mathrm{PhD}$ theses.

Design/methodology/approach - A historical study and an evaluation of current activities and future perspectives.

Findings - The ANRT has played a significant role in the back office of the French network for the dissemination and preservation of $\mathrm{PhD}$ theses for over forty years. Its online catalogue contains more than $200,000 \mathrm{PhD}$ theses that academic or other research institutions can order in print format or on microfiche. Complementary to this national mandate, the ANRT runs a print-on-demand service for more than 7,200 $\mathrm{PhD}$ theses called "Thèses à la carte". Today, the development of electronic theses and dissertations (ETD) and open access is challenging the future of the ANRT.

Originality/value - The ANRT Lille is one of those institutions that are more or less unknown to the wider public and even to LIS professionals. This paper presents it for the first time to a larger and international readership.
\end{abstract}

Keywords $\mathrm{PhD}$ theses, microform, digitizing, print-on-demand, document supply, scientific and technical information, France

\section{Paper type Case study}

The ANRT [1] Lille is one of those institutions that are more or less unknown to the wider public and even to LIS professionals. A small structure (less than twenty employees), the ANRT has played for over forty years a significant role in the back office of the French network for the dissemination and preservation of PhD theses. Today, the development of electronic theses and dissertations (ETD) and open access is challenging the future of the ANRT. It is time to review how the ANRT is working and develop some options for the future.

\section{A national mandate}

The history of the ANRT started when the French Ministry of Higher Education and Research decided on the creation of a national network for the dissemination and preservation of $\mathrm{PhD}$ theses (Vitoux, 1984). The idea was simple. [2]

On each of the French academic campuses, a local service was created for the handling of their PhD theses. After validation, one copy of the original print was sent to a national structure that reproduced it on microform. Based on the registration form, different information services produced the bibliographic record for a national database of $\mathrm{PhD}$ theses. From 2001 on, the local academic libraries created their records themselves directly in the national union catalogue called SUDOC. [3]

For nearly twenty years this infrastructure guaranteed the deposit of $\mathrm{PhD}$ theses, facilitated their identification and availability and moved the format of preservation and dissemination from print (offset) to microfiche (for more details, see Paillassard et al., 2007).

The national structure that reproduced the print copy on microform was called ANRT. Initially, the ANRT was created on two sites, in Lille for social sciences and humanities, economics and law and in Grenoble for sciences, medicine and technology but the activity of the Grenoble facility was later transferred to Lille. One of the models of the ANRT at that time was the UMI (now ProQuest) and their contribution to the dissemination of $\mathrm{PhD}$ theses from American universities (Power, 1946).

The national mandate of the ANRT was defined as "production, dissemination, and archiving of French PhD theses from all disciplines". To fulfil this mandate, the ANRT is funded by the government. Yet, this funding does not cover all related expenditures; the difference is assured/provided for by revenues from other sources. Human resources (16 employees) and budget are managed by the Lille 3 administration.

Reproducing the print copy on microform means that the ANRT prints an original microfiche on silver halide film for conservation, which is then duplicated on diazo-sensitised microfiches. The number of diazo copies depends on the discipline and varies between 50 and 80. The ANRT disseminates these copies each month to the French network of academic libraries for local preservation, consultation, and interlibrary loan and to other institutions on demand. This service is run upstream from the French academic interlibrary loan network. 
The ANRT maintains an online catalogue with more than 200,000 PhD theses that academic or other research institutions can order in print format or on microfiche. All these theses are preserved on microfiche on the ANRT site (see Figure 1).

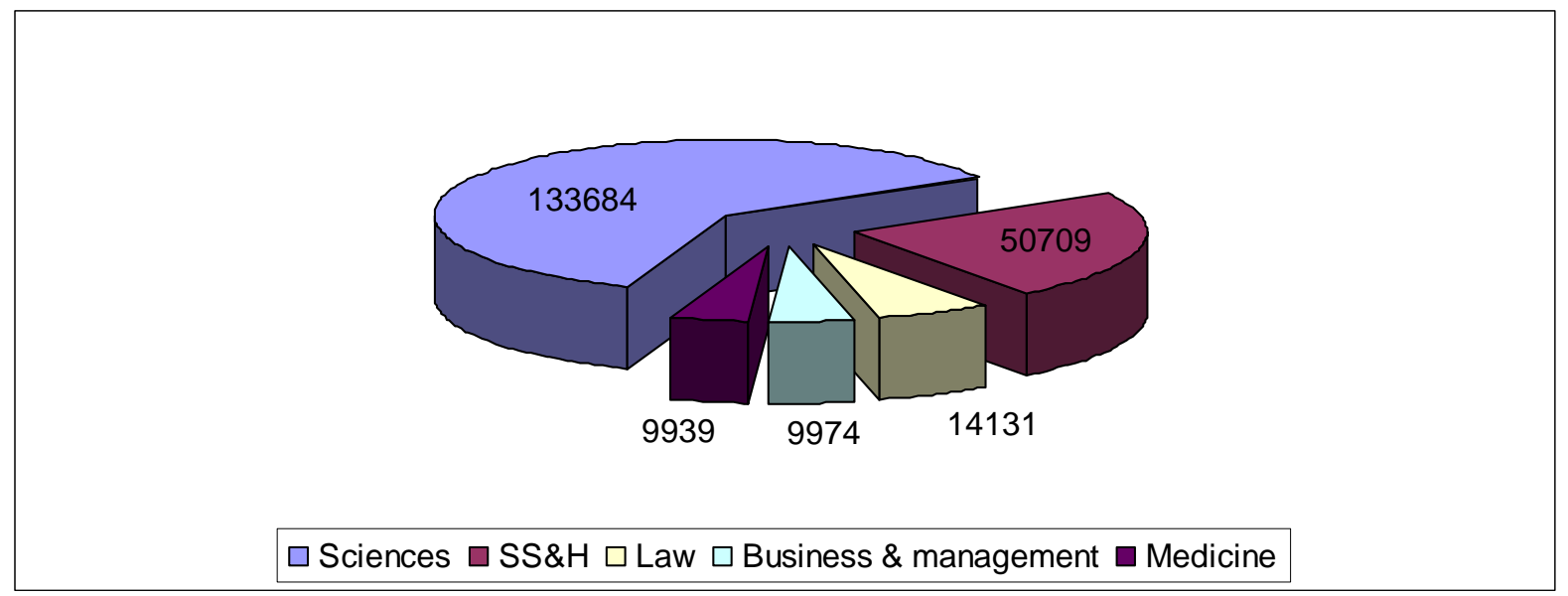

Figure 1 Disciplines of the ANRT microfiche holdings $(n=218,437)$

For more than ten years, the ANRT has transformed the former microform workflow into a modern digital production chain where all print copies are digitized and where microfiches are produced from the digital files (PDF format). So far, this computer-output-microform (COM) workflow has produced more than 70,000 digital files in TIFF format and partly in PDF (for the print-on-demand service, see below) that are safeguarded on an ANRT server.

\section{Print on demand}

Complementary to this national mandate, the ANRT runs a print-on-demand (POD) service for PhD theses called "Thèses à la carte". ANRT customers can order print copies from an online catalogue that contains more than 7,200 titles. "Thèses à la carte" allows for the dissemination of validated versions of a limited number of French $\mathrm{PhD}$ theses in a book format.

This service is based on bilateral and non-exclusive agreements with the authors (not with the institutions). In fact, the ANRT pre-selects interesting titles and contacts their authors with a licensing proposal. This means that the POD service does not concern all theses. The pricing depends on the number of pages and other features such as colour illustrations and covers the production-induced overheads.

During the period 2003-2012, the ANRT sold more than 53,000 POD items to customers from all around the world (Figure 2).

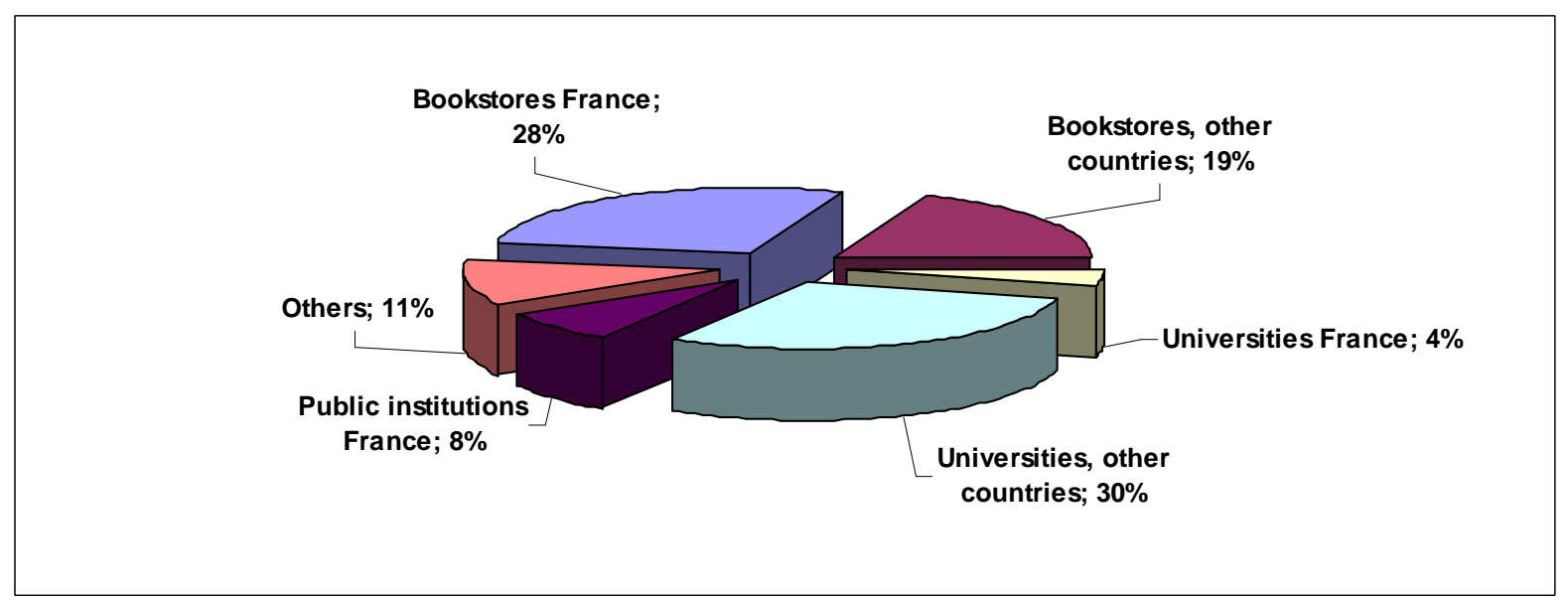

Figure 2 Customers of the print-on-demand service "Thèses à la Carte" 
Nearly half of the customers are scientific and academic bookstores in France and other countries, another third are university libraries and institutes mainly from North America and Asia. This activity is independent of interlibrary loan and document delivery.

\section{Digitising and other services}

The ANRT equipment includes microfiche, open book, and rapid scanners. This technical potential enables the ANRT to operate in other digitization projects. These projects are local which means that the ANRT partners are laboratories or libraries from the Lille universities.

In particular, the ANRT digitized several millions of pages of scientific heritage collections and older dissertations. This was done for instance, for the NordNum website on local history [4] run by the Lille 3 research laboratory on history [5] and for the IRIS repository on history of science and technology [6] run by the academic library of the scientific campus Lille 1.

Always on demand, the ANRT helps local PhD students to prepare their copies for the commission and prints copies from microfiches for the authors and/or their institutions ("micro-publishing").

\section{The emerging ETD environment}

After some years of discussion and experimentation, the French government launched a new infrastructure for the processing, dissemination and preservation of electronic theses and dissertations (ETD) in 2006. This infrastructure called STAR [7] allows universities to upload their ETD together with standard metadata. The digital file is archived on a central server at the French national Higher Education computation centre [8] and the metadata are transferred to the national union catalogue SUDOC and the portal Thèses.fr.

The main objective of the national infrastructure is long-term archiving and metadata handling. The choice as to how to disseminate the ETD is left with the local university. The university can decide to upload its ETD on a local server, for instance an institutional repository, on the national server of the STAR infrastructure, or on another site. In any case, STAR will handle the permanent link to the document. Together with the metadata, this link will provide access to the full-text via the ETD portal Thèses.fr (see also Colas, 2009).

More and more universities are moving to the new infrastructure. For the ANRT this means that the number of print $\mathrm{PhD}$ theses is steadily decreasing. And even regarding the remaining print copies, a recent survey on dissemination showed that the universities would prefer PDF files to microfiches. What is the future of the ANRT in this emerging ETD environment?

Actually, the ANRT explores three options:

Retro-digitization of the microfiche collection. Universities started locally and often without coordination to retro-digitize their own holdings of print $\mathrm{PhD}$ theses, most often in order to add the digital files to their institutional repositories. Retro-digitizing the microfiche collection could have three benefits/advantages; it would be faster and less expensive than local initiatives, and it would be comprehensive, at least it has been so for the last 30 years.

Printing microfiches from ETD. The long-term conservation of digital files is expensive and not without risk. Based on COM technology, the ANRT could maintain an inexpensive backup copy of the native digital files for the long term (100+ years) and conform to the LOCKSS [9] philosophy of risk reduction.

Print-on-demand service for ETD. For digital $\mathrm{PhD}$ theses that are not published elsewhere, a low-scale demand for print copies exists. Low-scale means/implies not enough to be interesting for commercial publishing. With its experience and equipment, the ANRT could run this service within the context of the public infrastructure for dissemination of ETD. Mittler and Schulz (2004), Wilson-Higgins (2011), and Geitgey (2011) discuss print-on-demand models which might serve as inspiration for the ANRT in this area.

As a matter of fact and due to copyright, an increasing number of ETD are available only on the campuses but not on the web. In this case, the traditional dissemination on microform may be an acceptable solution for authors and institutions. In the pursuit of its national mandate, the ANRT could guarantee this dissemination as an alternative to prohibited or unauthorized digital access.

\section{On the campus}

Alongside its national mandate, the ANRT is expanding its integration on the Lille campus. This integration is connected to both education and research.

Education. The ANRT already assists Lille PhD students during the preparation and submission of their dissertation. Since 2010, the site has also been organising internships for B.A. and Master students in subjects such as auditing, marketing, and image processing. Actually, the purpose of the ANRT is to become a technical support for new BA and Master programs in digital humanities, summer schools, etc. 
Research. The ANRT is developing a modular research program on the development of ETD as a specific case of academic publishing in change. This research program is a combination of service activities (best practices) and joint research on business models, legal environment, enhanced content, and scientometrics.

The ANRT is also contributing to a new publishing strategy on the Lille campus that will integrate its institutional repository publishing, university press publishing, and labelled support to the laboratories' journals and monographs.

\section{Value proposal for foreign customers}

What service can the ANRT offer to customers abroad? First of all, the ANRT offers one of the richest collections of recent French PhD theses, especially in social sciences and humanities. Foreign customers generally ask for two services: they order books via the POD service "Thèses à la Carte", and they ask for microfiche copies. Sometimes these orders (POD and microfiches) reflect an acquisition policy of collection building (research libraries, information centres). In other cases (only POD), the ANRT customers are intermediaries such as bookstores serving their own clients. Both cases are in line with the ANRT mandate, which is to contribute to the dissemination of French $\mathrm{PhD}$ theses and in particular, to disseminate theses on microfiches to higher education and research institutions.

What do customers appreciate? The ANRT conducted a survey in 2012. The customers - often regular and long-term customers - are globally satisfied with the quality of the ANRT service, more with customization, product quality, and personal contact than with pricing and delay. This means that the ANRT can make some progress in the future, even if serving the international communities will remain a marginal activity, adjacent and complementary to its national mandate.

\section{Conclusion}

The national mandate of the French ANRT is closely related to the infrastructure of print $\mathrm{PhD}$ theses. This infrastructure will gradually disappear in favour of the emerging infrastructure of ETD. Will the ANRT disappear with this fading landscape? Not necessarily.

On the one hand, someone has to maintain the microform archive and exploit it for the academic communities. This collection is unique in France, and it is not hidden but available for institutions as a kind of special document supply service, related to but outside (upstream) of the national interlibrary loan network.

On the other hand, the ANRT developed complementary services, such as print-on-demand and digitization of print material, images and so on that can survive without dissemination of microfiches.

Also, there may be a future for microfiche printing even alongside with digital dissemination and archiving of theses, not as an alternative but as a complement. For the preparation of this future, other studies and projects, such as the JISC-funded Digital Curation Centre, and exchange with other national and international stakeholders with experience in microform printing (ProQuest and so on) is important.

And hopefully there may be a future on the Lille campus, integrated as a technical support in education, research, and academic publishing.

\section{Notes}

1. ANRT stands for Atelier National de Reproduction des Thèses which means National Centre for the Reproduction of PhD Theses, see www.diffusiontheses.fr/.

2. See the 1985 decree at www.sup.adc.education.fr/bib/Acti/These/textregl.htm\#25sept.

3. For more information on SUDOC, Système Universitaire de Documentation, see www.sudoc.abes.fr/.

4. The NordNum web site is at http://nordnum.univ-lille3.fr/.

5. See http://irhis.recherche.univ-lille3.fr/ IRHIS for more information on the University of Lille research laboratory on history.

6. The IRIS repository on history of science and technology is available at http://iris.univ-lille1.fr/.

7. See the ABES website at http://en.abes.fr/Theses/National-assignment.

8. The CINES web site is at www.cines.fr/

9. See the LOCKSS web site at www.lockss.org/ Of course, LOCKSS is for digital preservation but the problem is the same - how to reduce related risk? Microfiche is one option.

All web sites accessed in October 2012.

\section{References}


Colas, A. (2009), "Administration centrale et bibliothèques universitaires. Vers une refondation des relations", Bulletin des Bibliothèques de France, Vol. 54 No. 6, pp. 6-11.

Geitgey, T. (2011), "The University of Michigan Library Espresso Book Machine experience", Library Hi Tech, Vol. 29 No. 1, pp. 51-61.

Mittler, E. and Schulz, M. (2004), "ProPrint world-wide print-on-demand services for study and research", Library Hi Tech, Vol. 22 No. 2, pp. 227-230.

Paillassard, P., Schöpfel, J. and Stock, C. (2007), "Dissemination and preservation of French print and electronic theses", The Grey Journal, Vol. 3 No. 2, pp. 77-93.

Power, E.B. (1946), "University Microfilms - a microfilming service for scholars", Journal of Documentation, Vol. 2 No. 1, pp. 23-31.

Vitoux, M.C. (1984), "Les thèses", Bulletin des Bibliothèques de France, Vol. 29 No. 2, pp. 158-160.

Wilson-Higgins, S. (2011), "Could print on-demand actually be the 'new interlibrary loan'?", Interlending \& Document Supply, Vol. 39 No. 1, pp. 5-8. 